\title{
Chapter 3 \\ Beyond Refugia: New Insights on Quaternary Climate Variation and the Evolution of Biotic Diversity in Tropical South America
}

Paul A. Baker, Sherilyn C. Fritz, David S. Battisti, Christopher W. Dick, Oscar M. Vargas, Gregory P. Asner, Roberta E. Martin, Alexander Wheatley, and Ivan Prates

\begin{abstract}
Haffer's (Science 165: 131-137, 1969) Pleistocene refuge theory has provided motivation for 50 years of investigation into the connections between climate, biome dynamics, and neotropical speciation, although aspects of the original theory are not supported by subsequent studies. Recent advances in paleoclimatology suggest the need for reevaluating the role of Quaternary climate on evolutionary history in tropical South America. In addition to the many repeated large-amplitude climate changes associated with Pleistocene glacial-interglacial stages ( $40 \mathrm{kyr}$ and $100 \mathrm{kyr}$ cyclicity), we highlight two aspects of Quaternary climate change in tropical South America: (1) an east-west precipitation dipole, induced by solar radiation changes associated with Earth's precessional variations
\end{abstract}

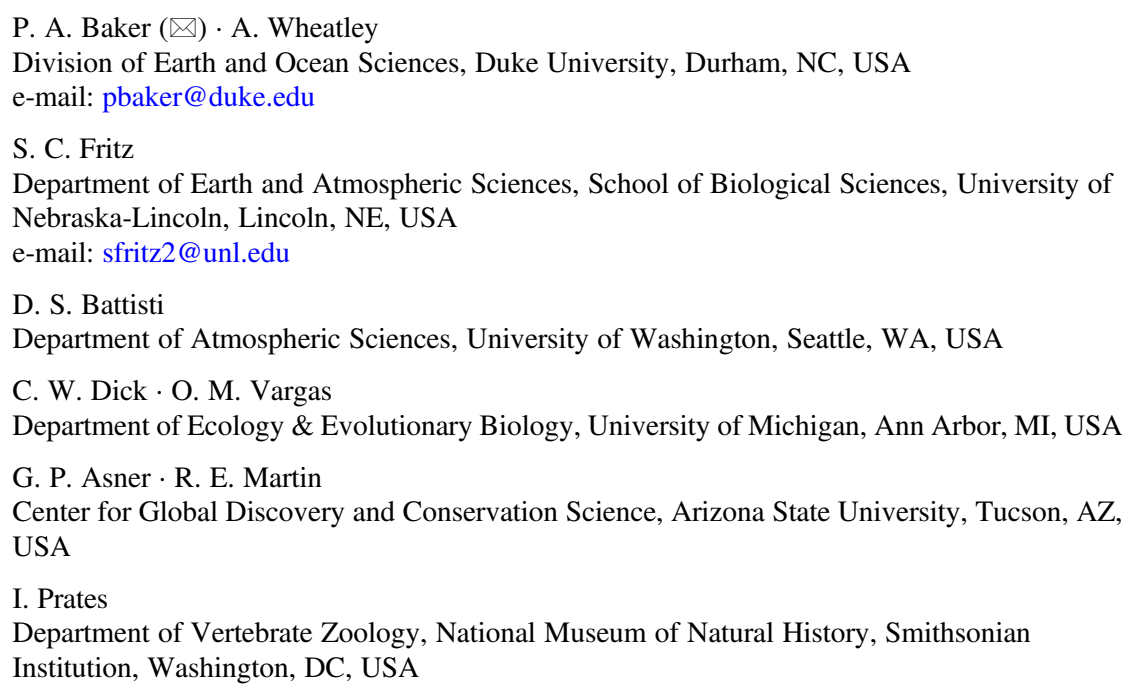


( 20 kyr cyclicity); and (2) periods of anomalously high precipitation that persisted for centuries-to-millennia (return frequencies $\sim 1500$ years) congruent with cold "Heinrich events" and cold Dansgaard-Oeschger "stadials" of the North Atlantic region. The spatial footprint of precipitation increase due to this North Atlantic forcing extended across almost all of tropical South America south of the equator. Combined, these three climate modes present a picture of climate change with different spatial and temporal patterns than envisioned in the original Pleistocene refuge theory.

Responding to these climate changes, biomes expanded and contracted and became respectively connected and disjunct. Biome change undoubtedly influenced biotic diversification, but the nature of diversification likely was more complex than envisioned by the original Pleistocene refuge theory. In the lowlands, intermittent forest expansion and contraction led to species dispersal and subsequent isolation, promoting lineage diversification. These pulses of climate-driven biotic interchange profoundly altered the composition of regional species pools and triggered new evolutionary radiations. In the special case of the tropical Andean forests adjacent to the Amazon lowlands, new phylogenetic data provide abundant evidence for rapid biotic diversification during the Pleistocene. During warm interglacials and interstadials, lowland taxa dispersed upslope. Isolation in these disjunct climate refugia led to extinction for some taxa and speciation for others.

Keywords Refugia - Tropical South America · Quaternary · Paleoclimate · Phylogenetics · Geogenomics

\section{Introduction}

Publication of Haffer's (1969) Pleistocene refuge theory encouraged researchers to seek connections between climate-biome dynamics and neotropical diversification. Based on centers of modern endemism identified respectively for birds and lizards, Haffer (1969) and Vanzolini and Williams (1970) independently proposed that pulses of forest contraction and expansion in the Amazon basin, driven by Pleistocene glacial-interglacial climate cycles, forced population isolation and divergence, promoting allopatric speciation in forest refugia. This model assumed largemagnitude drying of the Amazon during the global ice ages that produced the contraction of wet tropical forest into isolated patches with replacement of intervening forest by vast expanses of savanna. In recent years, the Pleistocene refuge theory for Amazonia has been rejected by some who found little evidence either for significant Pleistocene aridity or for forest fragmentation (Colinveaux et al. 1996; Bush et al. 2004). The contention was also made that crown-group ages in some groups of organisms date to the Neogene, in disagreement with the temporal framework of diversification implied in the Pleistocene refuge theory (Moritz et al. 2000; Hoorn et al. 2010; Prates et al. 2015). Yet phylogenetic studies across a wide range of plant and animal taxa increasingly point to the fact that many neotropical 


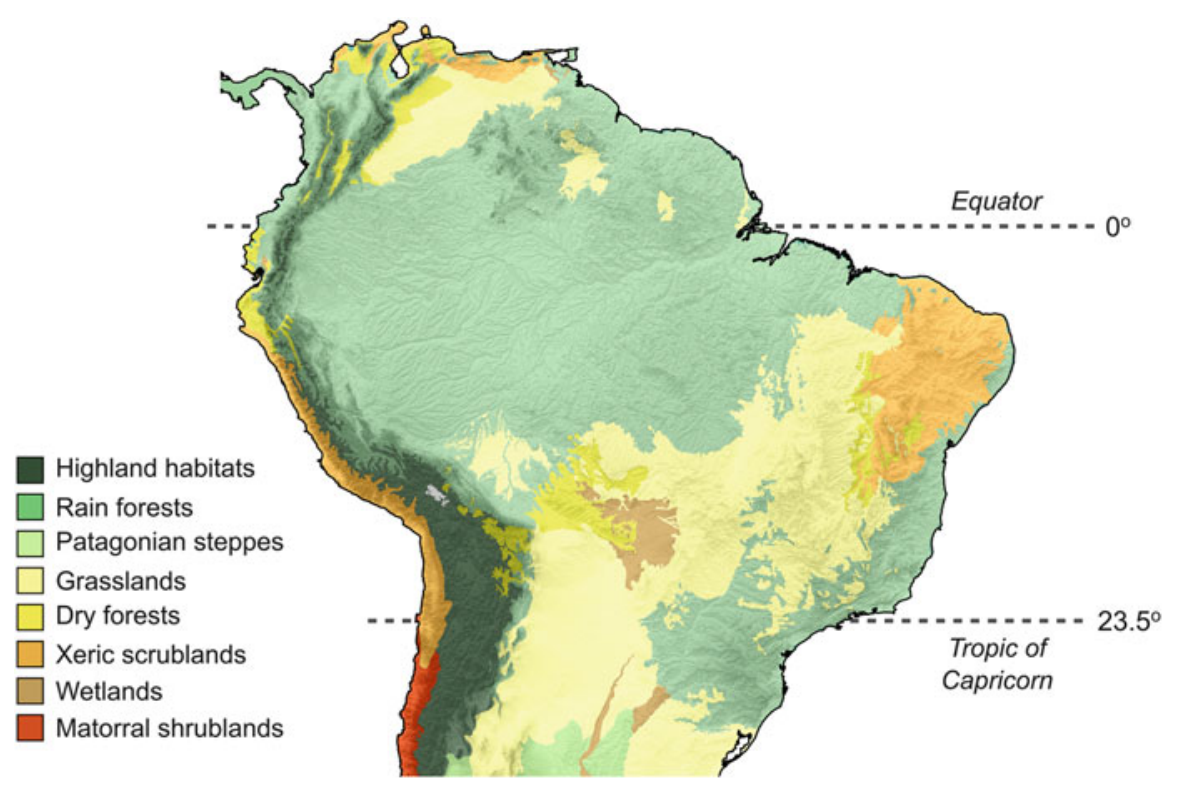

Fig. 3.1 Biome map of tropical South America depicting the distribution of highland habitats (paramo and montane forests in the Andes and Guiana Shield region), rain forests (including Amazonia, Chocó, and the Brazilian Atlantic Forest), Patagonian steppes, grasslands (including the Cerrado, Chaco, Pampas, and Venezuelan Llanos), dry forests, xeric scrublands (including the Brazilian Caatinga), wetlands (including the Brazilian Pantanal), and Chilean Matorral scrublands

sister species did actually diverge in the Pleistocene (Richardson et al. 2001; Hughes and Eastwood 2006; Madriñán et al. 2013; Garzón-Orduña et al. 2014; Koenen et al. 2015; Byrne et al. 2016), opening the possibility of a role for Quaternary climate variation in the diversification of these biota (Rangel et al. 2018; Wheatley et al. 2019, but see Rull and Carnaval 2019 and Vargas and Dick 2019).

In this contribution, we first review major advances in our knowledge of the nature of Quaternary paleoclimate variation at scales relevant to community compositional change and biotic diversification in tropical South America. We address if, and how, Quaternary climate variation affected forest distribution (Fig. 3.1) and composition, to the limited extent that we know either. Finally, we briefly discuss the evidence from biogeographic and phylogenetic studies relevant to the question of how regional taxa may have evolved during, and in response to, periods of Quaternary climate change. 


\section{Climate Variability During the Quaternary}

\subsection{Was Amazonia Drier During the Last Glacial Maximum (and Other Glacial Intervals of the Quaternary) Than It Is Today?}

We start our discussion of Quaternary climate variability by addressing the first question that has been oft revisited, but never definitively answered. Earth's global climate was stunningly different only 20,000 years ago, at the Last Glacial Maximum (LGM), compared to today. Atmospheric $\mathrm{CO}_{2}$ was reduced to $\sim 180 \mathrm{ppmv}$; large ice sheets were present across boreal continental regions, particularly in North America; global eustatic sea level dropped $120 \mathrm{~m}$ below present; and global air temperatures averaged ca. $5{ }^{\circ} \mathrm{C}$ colder than modern. In tropical South America, Andean snow lines lowered approximately $1 \mathrm{~km}$ and glacial erosion greatly increased the sediment load of Andean rivers and sediment delivery to inland basins (Fritz et al. 2007) and to the Atlantic Ocean. The Amazon continental shelf was exposed subaerially and likely became vegetation covered (Leite et al. 2016), and the Amazon river incised its course for nearly $300 \mathrm{~km}$ across the shelf, delivering much of its sediment load to the Amazon deep-sea fan (Nace et al. 2014). These changes during the LGM were only the latest manifestation of some 50 prior glacial stages that occurred over the past 2.6 million years: lower-amplitude warm-cold cycles every $40 \mathrm{kyr}$ from 2.6 to ca. $0.8 \mathrm{Ma}$ and higher-amplitude cycles every $100 \mathrm{kyr}$ since (Lisiecki and Raymo 2005).

A common and persistent misconception about Amazon paleoclimate is that the LGM (and earlier glacial stages) was drier than present throughout all of Amazonia. Whereas thermodynamics informs that ca. 35\% less water vapor can be held in saturated air due to the ca. $5{ }^{\circ} \mathrm{C}$ air temperature lowering deduced for the LGM in tropical South America (Stute et al. 1995), atmospheric dynamics can compensate for lower water vapor content by increasing low-level winds bringing moisture from its Atlantic source into the Amazon. Such an increase could have been brought about both by a southward shift of the zonal mean position of the western Atlantic Intertropical Convergence Zone (ITCZ) during the LGM (Black et al. 1999; Peterson et al. 2000; Baker et al. 2001a) and the posited strengthening of the northeast Trades (McGee et al. 2018). Summer insolation over South America was at a maximum during the LGM and intensified the South American summer monsoon (SASM) (Baker et al. 2001a, b; Cruz et al. 2005). Together, these three factors (ITCZ, trade winds, insolation) led to a generally high rate of precipitation, perhaps similar to modern, during the LGM in the SASM-region, i.e. the tropical central Andean region, the western Amazon, and subtropical South America. That conclusion is based on multiple lacustrine (e.g., Baker et al. 2001a, b; Baker and Fritz 2015) and speleothem (e.g., Cruz et al. 2005; Cheng et al. 2013) records of LGM climate from sites around the western and southern periphery of the Amazon (Fig. 3.2), from which we infer that western Amazon precipitation was high (i.e. comparable to modern) during the LGM (Table 3.1). 


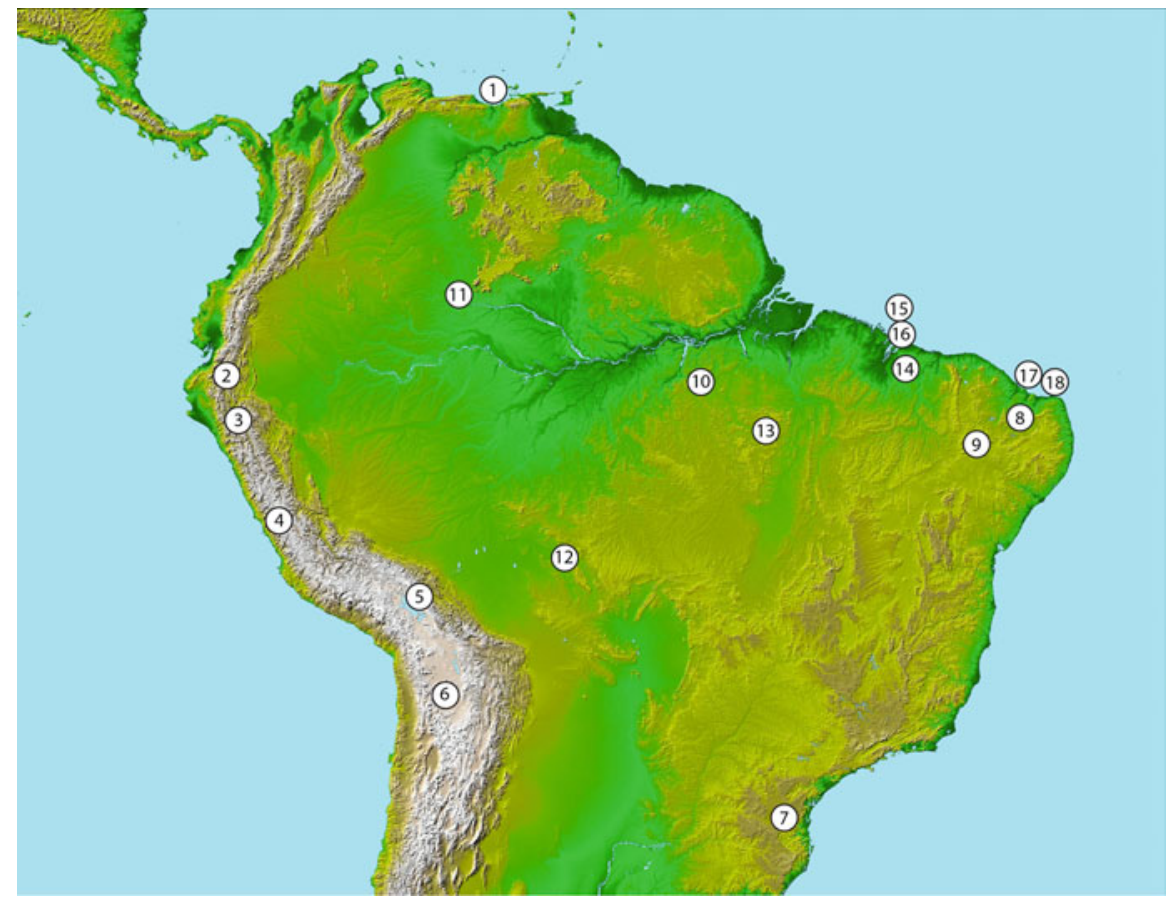

Fig. 3.2 Location of sites discussed in the text superimposed on a digital elevation model of South America. See Table 3.1 for site key and additional site details

Fewer paleoclimate records of the LGM exist from locations within the central and eastern parts of the Amazon basin and northeastern Brazil. Yet within the last decade, new speleothem records from northeastern Brazil (Cruz et al. 2009) and the eastern Amazon (Wang et al. 2017) indicate significant spatial variation of precipitation at orbital time scales across tropical South America. Specifically, Cruz et al. (2009) uncovered a precipitation dipole between the western Amazon/tropical central Andes and northeastern Brazil, varying with precessional (20 kyr) periodicity (Fig. 3.3). This finding was reinforced by a speleothem record from eastern Amazonia (Wang et al. 2017). Thus, in the western pole (western Amazonia, the tropical central Andes, the subtropics), precipitation increased during periods of increased summer insolation, while in the eastern pole (northeastern Brazil, the eastern Amazon), precipitation decreased during the same periods of higher summer insolation.

The spatial footprint of this precipitation dipole is not well defined, because of the limited number of paleoclimate sites. Moreover, the longest speleothem record from the eastern dipole region (Wang et al. 2017) only extends back to 45,000 years before present. Although no terrestrial paleoclimate records that are presently available can confirm its long-term persistence, the existence of the east-west precipitation dipole is a robust feature of many different climate models (Fig. 3.4) forced by 
Table 3.1 Paleoclimate proxy records shown on the map in Fig. 3.2. The location and type of record, the measured proxy, and the authors responsible for each study are included

\begin{tabular}{|c|c|c|c|c|c|c|c|}
\hline $\begin{array}{l}\text { Site } \\
\#\end{array}$ & Archive & Record & Proxies & References & Lat. & $\begin{array}{l}\text { Long } \\
{ }^{\circ} \mathrm{W}\end{array}$ & $\begin{array}{l}\text { Elev. } \\
\text { (m) }\end{array}$ \\
\hline 1 & Marine & $\begin{array}{l}\text { Caraico, } \\
\text { Venezuela }\end{array}$ & Color & $\begin{array}{l}\text { Peterson et al. } \\
\text { (2000) }\end{array}$ & $10.5^{\circ} \mathrm{N}$ & 65 & 0 \\
\hline 2 & Speleothem & $\begin{array}{l}\text { Santiago, } \\
\text { Ecuador }\end{array}$ & $\delta^{18} \mathrm{O}$ & $\begin{array}{l}\text { Mosblech et al. } \\
\text { (2012) }\end{array}$ & $3.02^{\circ} \mathrm{S}$ & 78.13 & 980 \\
\hline \multirow[t]{2}{*}{3} & Speleothem & $\begin{array}{l}\text { Diamante, } \\
\text { Perú }\end{array}$ & $\delta^{18} \mathrm{O}$ & $\begin{array}{l}\text { Cheng et al. } \\
\text { (2013) }\end{array}$ & $5.73^{\circ} \mathrm{S}$ & 77.5 & 960 \\
\hline & Speleothem & $\begin{array}{l}\text { El Condor, } \\
\text { Perú }\end{array}$ & $\delta^{18} \mathrm{O}$ & $\begin{array}{l}\text { Cheng et al. } \\
\text { (2013) }\end{array}$ & $5.93^{\circ} \mathrm{S}$ & 77.3 & 860 \\
\hline 4 & Speleothem & $\begin{array}{l}\text { Pacupahuain, } \\
\text { Perú }\end{array}$ & $\delta^{18} \mathrm{O}$ & $\begin{array}{l}\text { Kanner et al. } \\
\text { (2012) }\end{array}$ & $11.24^{\circ} \mathrm{S}$ & 75.82 & 3800 \\
\hline 5 & Lake & $\begin{array}{l}\text { Titicaca, } \\
\text { Bolivia/Perú }\end{array}$ & $\delta^{13} \mathrm{C}$ & $\begin{array}{l}\text { Baker et al. } \\
\text { ( } 2001 \mathrm{a}, \mathrm{b}) \text {, Fritz } \\
\text { et al. (2007, } \\
\text { 2010) }\end{array}$ & $16^{\circ} \mathrm{S}$ & 68.5 & 3810 \\
\hline 6 & Lake & $\begin{array}{l}\text { Uyuni, } \\
\text { Bolivia }\end{array}$ & Gamma & $\begin{array}{l}\text { Baker et al. } \\
(2001 \mathrm{a}, \mathrm{b})\end{array}$ & $20^{\circ} \mathrm{S}$ & 68 & 3653 \\
\hline 7 & Speleothem & $\begin{array}{l}\text { Botuverå, } \\
\text { Brazil }\end{array}$ & $\delta^{18} \mathrm{O}$ & Cruz et al. (2005) & $27.22^{\circ} \mathrm{S}$ & 49.15 & 230 \\
\hline 8 & Speleothem & $\begin{array}{l}\text { Rio Grande, } \\
\text { Brazil }\end{array}$ & $\delta^{18} \mathrm{O}$ & Cruz et al. (2009) & $5.6^{\circ} \mathrm{S}$ & 37.73 & 100 \\
\hline 9 & Groundwater & $\begin{array}{l}\text { Maranhao, } \\
\text { Brazil }\end{array}$ & $\begin{array}{l}\text { Noble } \\
\text { gas }\end{array}$ & Stute et al. (1995) & $7^{\circ} \mathrm{S}$ & 41.5 & 400 \\
\hline 10 & Speleothem & $\begin{array}{l}\text { Paraíso, } \\
\text { Brazil }\end{array}$ & $\delta^{18} \mathrm{O}$ & $\begin{array}{l}\text { Wang et al. } \\
\text { (2017) }\end{array}$ & $4.07^{\circ} \mathrm{S}$ & 55.45 & 60 \\
\hline 11 & Lake & $\begin{array}{l}\text { Hill of Six } \\
\text { Lakes, Brazil }\end{array}$ & Pollen & Bush et al. (2004) & $0.30^{\circ} \mathrm{N}$ & 66.67 & 75 \\
\hline \multirow[t]{2}{*}{12} & Lake & $\begin{array}{l}\text { Bella Viata, } \\
\text { Bolivia }\end{array}$ & Pollen & $\begin{array}{l}\text { Punyasena et al. } \\
\text { (2008), } \\
\text { Burbridge et al. } \\
\text { (2004) }\end{array}$ & $13.62^{\circ} \mathrm{S}$ & 61.55 & 225 \\
\hline & Lake & $\begin{array}{l}\text { Champlain, } \\
\text { Bolivia }\end{array}$ & Pollen & $\begin{array}{l}\text { Punyasena et al. } \\
\text { (2008), } \\
\text { Burbridge et al. } \\
\text { (2004) }\end{array}$ & $14.47^{\circ} \mathrm{S}$ & 61.07 & 225 \\
\hline 13 & Lake & $\begin{array}{l}\text { Carajas, } \\
\text { Brazil }\end{array}$ & Pollen & $\begin{array}{l}\text { Absy et al. } \\
(1991), \\
\text { Hermanowski } \\
\text { et al. (2012), Reis } \\
\text { et al. (2017) }\end{array}$ & $6.4^{\circ} \mathrm{S}$ & 50.42 & 730 \\
\hline 14 & Lake & Cacó, Brazil & Pollen & $\begin{array}{l}\text { Ledru et al. } \\
\text { (2006) }\end{array}$ & $2.97^{\circ} \mathrm{S}$ & 43.42 & 0 \\
\hline 15 & Marine & $\begin{array}{l}\text { CDH-86, } \\
\text { Brazil }\end{array}$ & XRF & Nace et al. (2014) & $0.33^{\circ} \mathrm{S}$ & 44.21 & 0 \\
\hline 16 & Marine & $\begin{array}{l}\text { GeoB- } \\
16,205, \\
\text { Brazil }\end{array}$ & Pollen & $\begin{array}{l}\text { Bouimetarhan } \\
\text { et al. (2018) }\end{array}$ & $1.21^{\circ} \mathrm{S}$ & 43.05 & 0 \\
\hline
\end{tabular}


Table 3.1 (continued)

\begin{tabular}{l|l|l|l|l|l|l|r}
\hline $\begin{array}{l}\text { Site } \\
\#\end{array}$ & Archive & Record & Proxies & References & Lat. & $\begin{array}{l}\text { Long } \\
{ }^{\circ} \mathrm{W}\end{array}$ & $\begin{array}{l}\text { Elev. } \\
(\mathrm{m})\end{array}$ \\
\hline 17 & Marine & $\begin{array}{l}\text { GeoB-3912, } \\
\text { Brazil }\end{array}$ & XRF & Arz et al. (1998) & $3.67^{\circ} \mathrm{S}$ & 37.43 & 0 \\
\hline 18 & Marine & $\begin{array}{l}\text { GeoB-3104, } \\
\text { Brazil }\end{array}$ & Pollen & $\begin{array}{l}\text { Behling et al. } \\
(2000)\end{array}$ & $3.67^{\circ} \mathrm{S}$ & 37.43 & 0 \\
\hline & $\begin{array}{l}\text { GeoB-3910, } \\
\text { Brazil }\end{array}$ & Pollen & $\begin{array}{l}\text { Dupont et al. } \\
(2010)\end{array}$ & $4.25^{\circ} \mathrm{S}$ & 36.34 & 0 \\
\hline
\end{tabular}

Fig. 3.3 Sketch of the temporal evolution of precipitation of the eastern and western Amazon through one precession (20 kyr) cycle

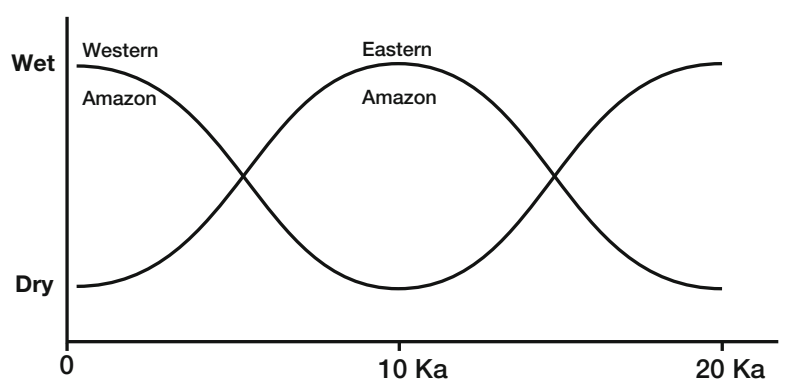

Fig. 3.4 A map of the east to west precipitation dipole in tropical South America on precession time scales (20 kyr) that shows the difference in DJF precipitation $\left(\mathrm{mm} \mathrm{d}^{-1}\right)$ observed between low summer insolation (218 Ka) and high summer insolation (207 Ka) experiments. From Liu and Battisti (2015)

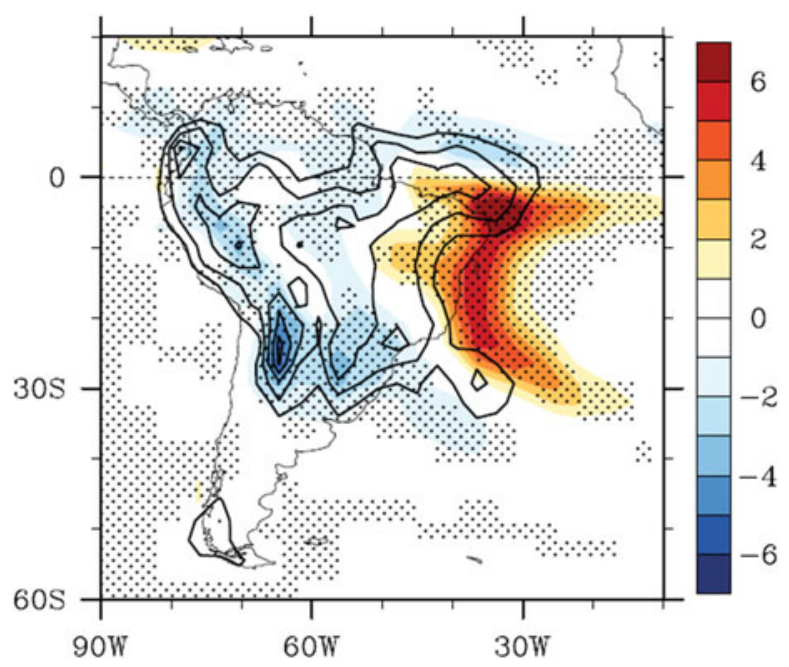

precessionally induced changes in insolation (Prado et al. 2013; Liu and Battisti 2015).

Wang et al. (2017) calculated on the basis of their speleothem isotopic record that precipitation during the LGM was 58\% of modern in the eastern Amazon region, supporting the idea of a drier eastern Amazon at this time. However, they failed to adjust speleothem oxygen isotopic values for the estimated $5{ }^{\circ} \mathrm{C}$ cooling at the LGM (Stute et al. 1995) and changes in seawater $\delta^{18} \mathrm{O}$ (Schrag et al. 2002). When their 
speleothem record is corrected for these two effects (by subtracting 2\%o from the LGM speleothem $\delta^{18} \mathrm{O}$ value, see Baker and Fritz 2015), LGM $\delta^{18} \mathrm{O}$ values nearly match modern $\delta^{18} \mathrm{O}$ values in the same speleothem, from which we conclude that LGM precipitation was nearly equal to modern levels. That is, LGM precipitation in the eastern Amazon was similar to modern precipitation in that region, although relatively low compared to contemporaneous precipitation levels from regions farther west. The corrected record indicates that it was the early-to-mid Holocene time period ( $\sim 9000-5000$ years before present) that had exceptional levels of precipitation. This period was evidently far wetter-than-modern in the eastern Amazon, while far drier-than-modern in the western Amazon (Punyasena et al. 2008) and tropical central Andes (Baker et al. 2001a; Cross et al. 2001).

In conclusion, data and models agree that there were large-amplitude fluctuations in precipitation amount on precessional time scales for the past 40,000 years in the near-equatorial regions, with drier conditions in the east accompanied by wetter conditions in the west, and vice versa. Furthermore, models suggest that that this east-west precipitation dipole existed throughout the entire Quaternary and prior to that. However, the exact spatial footprint of the dipole, the magnitude of precipitation change, and its impact on the forest and associated biota, all remain to be determined. Whereas it is evident from the data that spatially variable regions of climate change and forest expansion/contraction (e.g. Cheng et al. 2013) did not resemble the patterns envisioned by Haffer (1969), it is expected that climate-driven variation of forest biomes during the Quaternary had a profound influence on biotic dispersal, gene flow, and divergence (see below).

\subsection{Short-Term (Millennial) Extreme Precipitation Events: Were They Sufficient to Establish or Destroy Forested Habitat?}

Some of the intervals of most extreme precipitation change in tropical South America during the late Quaternary are not tied to gradual variations in insolation driven by orbital forcing but instead were shorter-duration anomalies, persisting for several hundred to a few thousand years. This "millennial variability" is associated with large changes in sea surface temperatures in the North Atlantic region.

One example of such millennial variability, predominantly present during the last glacial stage, is Dansgaard-Oeschger (D-O) cyclicity. D-O cycles were first identified in the oxygen isotopic record of Greenland ice cores and determined to be warmcold oscillations of air temperature (Dansgaard et al. 1993). Approximately 25 D-O cycles occurred between 90 and $10 \mathrm{Ka}$ (Rahmstorf 2002). D-O cyclicity is also present in Antarctic ice cores (Steig and Alley 2002), where temperatures are antiphased with Greenland (the "bipolar seesaw") and amplitudes are of lower magnitude (see Pedro et al. 2018 and references therein). D-O cyclicity is recorded in sea-surface temperature proxies from North Atlantic sediment and is widespread 
elsewhere in the Northern Hemisphere (Voelker 2002). D-O cyclicity affected precipitation across the Neotropics: cold periods in the North Atlantic are associated with an apparent intensification of the SASM and increased precipitation everywhere in tropical South America south of the equator (Fritz et al. 2010; Kanner et al. 2012; Cheng et al. 2013; Wang et al. 2017), with the possible exception of the Pacific coast. How this persistent millennial variation during glacial stages impacted biotic communities in the heart of Amazonia remains to be addressed. The regional instability associated with the occurrence of at least a couple dozen pulses of alternating increased and decreased precipitation over such a short period (i.e., $\sim 80 \mathrm{ky}$ ) may have led to recurrent extirpation of forest organisms in northeastern Brazil. This dynamic may explain a pattern of lower species richness in eastern, as compared to the climatically more stable western, Amazonia (e.g., Jenkins et al. 2013).

Heinrich events are a second type of millennial climate variability during glacial stages, closely related to D-O stadials ("stadials" are the cold phases of the D-O cycles). Heinrich events appear to occur only during the most extreme D-O stadials. Heinrich events are characterized by the massive discharge of icebergs, primarily derived from the Laurentide Ice Sheet, into the North Atlantic Ocean (Broecker 1994). Subsequent melting of the icebergs significantly decreased sea-surface salinity of the North Atlantic, possibly shutting down the Atlantic meridional overturning circulation and increasing the abundance of sea ice in the North Atlantic. Although both the causes and the consequences of Heinrich events are still debated, there is no doubt that large-scale climate impacts, synchronous with the Heinrich events, were felt in many far-field regions (Hemming 2004; Vellinga and Wood 2002). Paleoceanographic records from the Brazilian continental margin (Arz et al. 1998; Nace et al. 2014) document large increases of river runoff in northeastern Brazil synchronous with Heinrich events. On the Altiplano of Bolivia, Heinrich Event 1 (H1) brought about flooding and major expansion of now dry lakes (Sylvestre et al. 1999; Baker et al. 2001b). And Heinrich events coincide with the most negative $\delta^{18} \mathrm{O}$ values (indicating peak wet conditions) in speleothem records from the central Andes of Peru (Kanner et al. 2012), the western Amazon (Mosblech et al. 2012; Cheng et al. 2013), and the eastern Amazon (Wang et al. 2017).

Thus, D-O stadials and Heinrich events had similar impacts on tropical South American climate (Fig. 3.5), although Heinrich events were apparently associated with more extreme climates than were the D-O stadials (Zhang et al. 2017), consistent with the fact that the former represented more extreme cold conditions in the North Atlantic region. Paleoclimate data show that wet climates associated with these North Atlantic cold events occurred simultaneously across all of tropical South America, south of the equator, in both eastern and western regions. Some of these wet events lasted as long as 5000 years (Nace et al. 2014), although most were shorter in duration. It seems likely that these North Atlantic warm-cold swings, associated respectively with large amplitude dry-wet swings in tropical South America, brought about profound changes in forest composition and extent. Ecological studies have found that the recovery of rain forest following disturbance happens quickly, within only a couple hundred years (Liebsch et al. 2008). Moreover, vertebrate species can diffuse through thousands of kilometers of suitable 

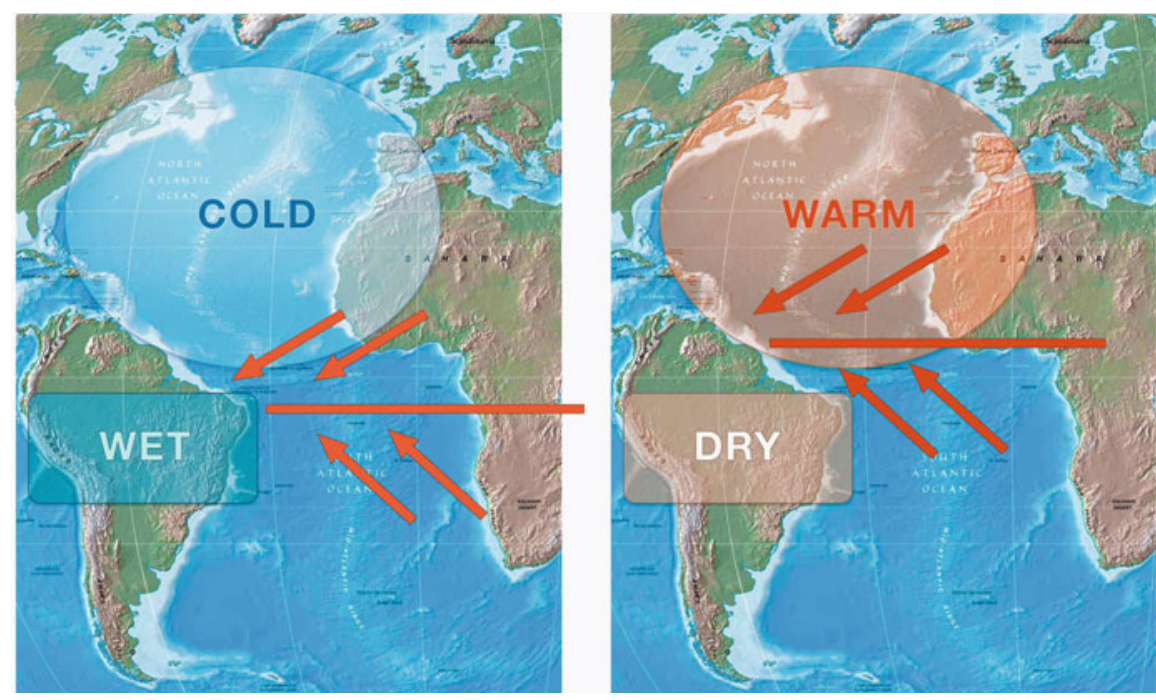

Fig. 3.5 A sketch of the impact of millennial cold and warm variability in the North Atlantic region on the position of the ITCZ and trade winds and on precipitation throughout tropical South America. See text for additional details

habitat within only a few decades, as suggested by ecological studies of amphibian, mammal, and bird species (Phillips et al. 2007; Stodart and Parer 1988; Wehtje 2003). As a result, the temporal scale of the climatic shifts implicated in D-O stadials and Heinrich events certainly was sufficient to lead to pronounced changes in habitat and species distributions in northern South America.

\section{Biological Responses to Quaternary Climate Variation}

\subsection{Biome Expansions and Contractions in Response to Orbital and Millennial Climate Change: Was Pleistocene Climate Variability Responsible for Speciation?}

Paleoecological data compiled over the last few decades suggest that tropical forest composition was dynamic in response to changes in climate, but there remains little evidence of large-scale shifts in the geographic distribution of major Amazonian biomes on glacial to interglacial time scales as envisioned by Haffer (Bush et al. 2004). The apparent persistence of wet tropical forest in the western to central Amazon (e.g., Cheng et al. 2013) has major implications for evolutionary studies of other organisms associated with forest settings. For instance, some animal populations may have remained stable even when faced with temporal turnover of 
tree species, as long as the structural forest environment remained similar over time. Yet, the paucity of sites in present-day Amazon forest and of records that date back more than $\sim 60,000$ years means that we still have a very incomplete picture of variability in the distribution and species composition of regional biomes through time (Fig. 3.1). While the available information points to stability of wet tropical forests in western to central Amazonia, there is clear evidence of biome expansion and contraction near rainforest-savanna ecotones in the southern and eastern Amazon regions (Absy et al. 1991; Burbridge et al. 2004; Hermanowski et al. 2012; Reis et al. 2017).

Pollen data also suggest vegetation responses to the large wet millennial events of the late-Quaternary in regions marginal to, but outside of, Amazonia. In areas of northeastern Brazil now occupied by semi-arid Caatinga, humid gallery forests apparently expanded during Heinrich 1 and the Younger Dryas events (Behling et al. 2000; Ledru et al. 2006; Dupont et al. 2010; Bouimetarhan et al. 2018). This forest expansion may have been sufficiently extensive to have produced a landscape mosaic with wet forest corridors connecting the Atlantic and eastern Amazon forests (Cheng et al. 2013; Bouimetarhan et al. 2018). However, phylogenetic evidence of dispersal events through gallery forests in the open habitats of central and northern Brazil is currently lacking.

Phylogenetic patterns in distinct organisms suggest links between Quaternary climate variation and population divergence. Patterns of genetic structure in species that colonized the Atlantic Forest from Amazonia indicate population genetic differentiation following forest contraction and biome separation (Dal-Vechio et al. 2018; Prates et al. 2018). These climate-driven events of population divergence, inferred to have happened recently, provide a mechanism to explain speciation and new evolutionary radiations also at deeper timescales. For example, a pattern of sister relationships between species and clades from Amazonia and the Atlantic Forest in several bird and small mammal groups (Costa 2003; Batalha-Filho et al. 2013) is consistent with the hypothesis that expansion of open and dry habitats (i.e., Caatinga dry forest and Cerrado savanna) following intervals of wet forest expansion favored speciation of rainforest organisms.

Lastly, climatic stability may contribute to the accumulation of biodiversity at regional spatial scales. In an example from the Atlantic Forest region, Carnaval et al. $(2009,2014)$ tested whether vertebrate phylogenetic endemism was related to forest persistence over the last $120 \mathrm{kyr}$. Their analysis, using climate model output, suggests that forest stability was a necessary factor for maintaining high levels of lineage endemism. However, different factors best explain patterns of endemism in the northern and southern regions of the Atlantic Forest; whereas lineage endemism is better predicted by climatic stability through time in the north, spatial climatic heterogeneity was a more important predictor of lineage endemism in the south. Such examples of integration of geologic and genetic approaches (geogenomics, sensu Baker et al. 2014) provide a potentially powerful means of testing models of how climatic history has affected evolutionary history and shaped current spatial patterns of biodiversity. 


\subsection{Shifts in Community Composition Through Climate-Mediated Dispersal}

Studies of diversification in Amazonian organisms have often emphasized in situ speciation, but the composition of local species pools is also strongly affected by migration between regions (Wiens 2004; Antonelli et al. 2018), and several examples of climate-mediated dispersal during the Quaternary have been proposed for Amazonia. For instance, a stepping-stone like corridor of dry vegetation formations may have favored migration of dry-adapted tree species (Bush 1994) and viperid snakes (Quijada-Mascareñas et al. 2007) through an otherwise wet forest matrix. Similarly, climate-driven geomorphic processes that affected the distribution of sandy soils may have created corridors for dispersal of dry-adapted taxa (D'Apolito et al. 2017); alternatively, drier conditions may have permitted dispersal of white sand forest specialists within a former non-analog forest matrix (Capurucho et al. 2013). The patchy distribution and low species endemism of the physiognomically distinctive white sand flora across the Amazon basin (Adeney et al. 2016) support the latter idea. In addition, pollen records suggest that cold-adapted upland tree taxa (e.g. Podocarpus) descended to the lowlands and expanded through the Amazon forest in response to past climate cooling (Colinveaux et al. 1996), creating assemblages that have no modern analog (Bush et al. 2004; Reis et al. 2017). These episodes of range expansion, followed by subsequent extinction within a wetter Amazon, could explain plant disjunctions between the Guiana Shield and Andean slopes (Berry and Riina 2005).

Climate-driven opportunities for dispersal may have produced large-scale biogeographic interactions between Amazonia and other South American biomes, with pronounced effects on the composition of regional assemblages. For instance, reconstructions of population history on the basis of genetic data from vertebrate taxa point to the establishment of rainforest corridors connecting eastern Amazonia with the northern Atlantic Forest in northeastern Brazil during the Pleistocene (Batalha-Filho et al. 2013; Dal-Vechio et al. 2018; Prates et al. 2016a, b, 2018). This finding is consistent with reconstructed pulses of increased precipitation on the basis of speleothem records, as discussed above (Cheng et al. 2013). Thus, climatedriven habitat shifts may have affected biotic composition and associated gene pools in Amazonia and adjacent regions by favoring dispersal.

\subsection{Perspectives on Climate, Topography, Soils, and Diversification in the Quaternary}

An increasing number of studies support a direct link between Pleistocene climatic variability, dispersal, and speciation in tropical South America. Several groups of lowland rain forest and Andean taxa diversified during the Pleistocene (e.g., Richardson et al. 2001; Kay et al. 2005; Hughes and Eastwood 2006; Lavin 2006; Erkens 
et al. 2007; Pouchon et al. 2018), and patterns of phylogenetic structure in birds, mammals, and reptiles support pulses of forest expansion that are spatially congruent across taxa, such as in present-day northeastern Brazil (Batalha-Filho et al. 2013; Costa 2003; Dal-Vechio et al. 2018; Prates et al. 2016b). The timing of population divergence and speciation for many taxa, as well as the inferred routes of range shifts, match expectations derived from the known variability of Pleistocene climate. These large-amplitude climate shifts extended not only into the Amazon basin but also into higher elevations in the tropical Andes.

Pleistocene climate variability superimposed upon pre-existing Andean topography provides a mechanism for driving speciation in high relief terrains. It has been suggested for plants (Gentry 1982) and frogs (Santos et al. 2009) and recently modeled (Rangel et al. 2018; Wheatley et al. 2019) that a significant proportion of the taxonomic diversification of tropical South America has arisen in the tropical Andes. Although Neogene and earlier history may explain some of this diversity (Luebert and Wiegend 2014; Antonelli et al. 2009), many Andean diversification events are recent, overlapping with the timing of Quaternary climatic dynamism (van der Hammen and Cleef 1986; Madriñán et al. 2013). Under interglacial or interstadial warm conditions, montane forest and alpine taxa colonize upslope, where populations may be disjunct from each other because of topographic isolationvalleys form genetic barriers whose taxon-specific effective porosity is related to their width, depth, and the physiological tolerances of different organisms (e.g., Wiens 2004). Subsequent cooling can reconnect isolated populations as they disperse downhill, encouraging genetic exchange between formerly disjunct populations, but also introducing newly divergent species back into the lowlands. Mountain tops thus serve as real climate refugia promoting allopatric speciation boosted by biotic interactions and ecological divergence (Lagomarsino et al. 2016; Vargas and Simpson 2019).

The Andes are only the most extreme of the mountains that circumscribe the Amazon. Lower-elevation ranges, such as the Guianan tablelands and Roraima to the north, the Serra do Divisor to the west, the Serra dos Gradaus and Serra do Cachimbo to the south, virtually surround the central Amazon basin. Pleistocene climate variability is known to have strongly impacted the biota of at least some of these regions (e.g., Reis et al. 2017), and new species may have arisen in these regions by climate-driven dispersal followed by isolation on mountain tops, a mechanism similar to that proposed for the Andes. Moreover, novel taxa originating in these high elevation habitats adjacent to Amazonia may have dispersed downward, providing lineages to central Amazonia (Santos et al. 2009).

Another important layer needed to improve our understanding of how Quaternary climate change affected neotropical biotas is the synergistic influence of geological substrate and soils. For example, although it has been posited that seasonally dry forests are currently restricted into their "refugia" and were more broadly distributed during the LGM (Pennington et al. 2000), the absence of rich, high pH soils between contemporary dry forests would have hindered their broad expansion. Although the distribution of soils has been poorly mapped in the Andes-Amazon region, the functional response of the tree canopy to spatially-varying substrate has been 
resolved at local scales and mapped over large biogeographic areas (Asner et al. 2015), providing new tools for assessing potential edaphic and nutrient influences on biodiversity and its origins.

Climate variability may also help to explain attributes of ecological communities. This is the case, for instance, in the observation that many tree species in the Amazon region are rare. It is possible that the low abundances of these species represent population declines in response to climatic shifts, while more favorable climates in the past may have sustained larger populations. Similarly, periodic mixing and population changes associated with spatio-temporal climate variability may explain why Amazon tree communities are widely dispersed and appear to have little community phylogenetic structure (Dexter et al. 2017). Lastly, climate variability may also help to explain how drought-tolerant and drought-intolerant plant species come to reside in the same forests (Esquivel-Muelbert et al. 2019).

\section{Conclusions}

Although Haffer (1969) posited large climate and biome variation during the Quaternary, at the time of his publication he could not marshal supporting paleoclimatic or paleobiotic information. Paleoclimatic studies during the intervening decades have fully established that there was very large, extrinsically forced, coherent, climate variation during the Quaternary across the Amazon, northeastern Brazil, subtropical Brazil, and the tropical Andes. It is now clear that the Amazon basin as a whole was not uniformly drier-than-modern during Pleistocene glacial intervals. For instance, the western Amazon, the central Andes, and the southeastern sub-tropics were similarly wet as at present during the LGM, whereas the eastern Amazon/ northeast Brazil region was similarly dry as today. Past wet and dry intervals of the Quaternary occurred on both orbital and millennial timescales, and the spatial footprints of wet and dry regions also varied, both east-west and north-south. In particular, large precipitation and effective moisture increases occurred coherently on millennial timescales across all of tropical South America, south of the equator, concurrent with cold "Heinrich events" and D-O stadials of the North Atlantic region. In short, Quaternary climate variation was neither monolithic nor necessarily contemporaneous solely with global glacial-interglacial cycles; rather the pacing and spatial footprint of past climates varied on both orbital and sub-orbital timescales.

Genetic evidence from a range of taxa is consistent with the hypothesis that alternately wet and dry conditions during the Quaternary brought about pulses of forest expansion and contraction. Biogeographic investigations of forest taxa recovered population changes and speciation events within the temporal and spatial scales implicated in climatic change associated with the precession cycles, Heinrich events, and D-O stadials. These pulses of climate-driven habitat shifts had dramatic effects on the composition of regional species pools and likely contributed to diversification. For instance, changes in habitat distribution led to connections and biogeographic exchange among presently distinct neotropical biomes, such as Amazonia 
and the Atlantic Forest. Moreover, forest contraction concomitant with the expansion of open and dry regions (such as the Cerrado and Caatinga) led to separation of major forested regions; isolated in these "mega-refugia", forest populations diverged and became new species, and species became new clades. The genetic evidence also supports that Quaternary climate variation promoted explosive radiations in the regions of high topographic relief surrounding central Amazonia, which subsequently provided lineages and increased the diversity of lowland forests. New biological and paleoenvironmental data convincingly support that Quaternary climate variation played a major role in evolutionary diversification in tropical South America. The responses of co-distributed organisms to these climate dynamics may have been mediated, to some extent, by distinct ecological tolerances and their underlying physiological and life history traits (Prates et al. 2016a, b).

Acknowledgements Writing of the manuscript was supported by a NASA workshop grant (NASA 15-BIODIV15-0013) to SF, as well as by NSF EAR-1338694 to PB, SF, DB, and $\mathrm{CD}$. We are grateful to the Charles Darwin Foundation, Galapagos for their support during the writing of an initial version of this manuscript. John Megahan, University of Michigan, assisted with graphics.

\section{References}

Absy ML, Cleef A, Fornier M, Servant M, Siffedine A, Da Silva MF, Soubies F, Suguio K, Turcq B, Van der Hammen T (1991) Mise en evidence de quatre phases d'ouverture de la foret dense dans le sud-est de L'Amazonie au cours des 60,000 dernieres annees. Premiere comparaison avec d'autres regions tropicales. C R Acad Sci II 312:673-678

Adeney JM, Christensen NL, Vicentini A, Cohn-Haft M (2016) White-sand ecosystems in Amazonia. Biotropica 48:7-23

Antonelli A, Nylander JAA, Persson C, Sanmartin I (2009) Tracing the impact of the Andean uplift on Neotropical plant evolution. Proc Natl Acad Sci U S A 106:9749-9754. https://doi.org/10. 1073/pnas.0811421106

Antonelli A, Zizka A, Carvalho FA, Scharn R, Bacon CD, Silvestro D, Condamine FL (2018) Amazonia is the primary source of Neotropical biodiversity. Proc Natl Acad Sci U S A 115:6034-6039. https://doi.org/10.1073/pnas.1713819115

Arz HW, Patzold J, Wefer G (1998) Correlated millennial-scale changes in surface hydrography and terrigenous sediment yield inferred from last-Glacial marine deposits off Northeastern Brazil. Quat Res 50:157-166

Asner GP, Anderson CB, Martin RE, Tupayachi R, Knapp DE, Sinca F (2015) Landscape biogeochemistry reflected in shifting distributions of chemical traits in the Amazon forest canopy. Nat Geosci 8:567-573

Baker PA, Fritz SC (2015) Nature and causes of Quaternary climate variation of tropical South America. Quat Sci Rev 124:31-47

Baker PA, Seltzer GO, Fritz SC, Dunbar RB, Grove M, Tapia P, Cross S, Rowe H, Broda J (2001a) The history of South American tropical climate for the past 25,000 years. Science 291:640-643

Baker PA, Rigsby CA, Seltzer GO, Fritz SC, Lowenstein T, Bacher N, Veliz Y (2001b) Tropical climate changes at millennial and orbital timescales revealed by deep drilling on the South American Altiplano. Nature 409:698-701 
Baker PA, Fritz SC, Dick CW, Eckert AJ, Horton BK, Manzoni S, Ribas CC, Garzione CN, Battisti DS (2014) The emerging field of geogenomics: constraining geologic problems with genetic data. Earth Sci Rev 135:38-47

Batalha-Filho H, Fjelsa J, Fabre P-H, Yumi C (2013) Connections between the Atlantic and the Amazonian forest avifaunas represent distinct historical events. J Ornithol 154:41-50

Behling H, Arz HW, Patzold J, Wefer G (2000) Late Quaternary vegetational and climate dynamics in northeastern Brazil, inferences from marine core GeoB 3104-1. Quat Sci Rev 19:981-994

Berry PE, Riina R (2005) Insights into the diversity of the Pantepui Flora and the biogeographic complexity of the Guayana Shield. Biologiske Skrifter 5:145-167

Black DE, Peterson LT, Overpeck JT, Kaplan A, Evans MN, Kashgarian M (1999) Eight centuries of North Atlantic Ocean atmosphere variability. Science 286:1709-1713

Bouimetarhan I, Chiessi C, Gonzalez-Arango CG, Dupont L, Voigt I, Prange M, Zonneveld K (2018) Intermittent development of forest corridors in northeastern Brazil during the last deglaciation: climatic and ecologic evidence. Quat Sci Rev 192:86-96

Broecker WS (1994) Massive iceberg discharges as triggers for global climate change. Nature 372:421-424

Burbridge RE, Mayle FE, Killeen TJ (2004) Fifty-thousand year vegetation and climate history of Noel Kempff Mercado National Park, Bolivian Amazon. Quat Res 61:215-230

Bush MB (1994) Amazonian speciation: a necessarily complex model. J Biogeogr 21:5-18

Bush MB, De Oliveira PE, Colinvaux PA, Miller MC, Moreno JE (2004) Amazonian paleoecological histories: one hill, three watersheds. Palaeogeogr Palaeoclimatol Palaeoecol 214:359-393

Byrne H, Rylands AB, Carneiro JC, Alfaro JWL, Bertuol F, Silva MNF, Messias M, Groves CP, Mittermeier RA, Farias I, Hrbek T, Schneider H, Sampaio I, Boubli JP (2016) Phylogenetic relationships of the New World titi monkeys (Callicebus): first appraisal of taxonomy based on molecular evidence. Front Zool 13:10. https://doi.org/10.1186/s12983-016-0142-4

Capurucho JMG, Cornelius C, Borges SH, Cohn-Haft M, Aleixo A, Metzger JP, Ribas CC (2013) Combining phylogeography and landscape genetics of Xenopipo atronitens (Aves: Pipridae), a white sand campina specialist, to understand Pleistocene landscape evolution in Amazonia. Biol J Linn Soc 110:60-76

Carnaval AC, Hickerson MJ, Haddad CFB, Rodrigues MT, Moritz C (2009) Stability predicts genetic diversity in the Brazilian Atlantic forest hotspot. Science 323:785-789

Carnaval AC, Waltari E, Rodrigues MT, Rosauer D, VanDerWal J, Damasceno R, Prates I, Strangas M, Spanos Z, Rivera D, Pie MR, Firkowski CR, Bornschein MR, Ribero LF, Moritz $\mathrm{C}$ (2014) Prediction of phylogeographic endemism in an environmentally complex biome. Proc R Soc B 281:20141461

Cheng H, Sinha A, Cruz FW, Wang X, Edwards LR, d'Horta FM, Ribas CC, Vuille M, Stott LD, Auler AS (2013) Climate change patterns in Amazonia and biodiversity. Nat Commun 4:1411

Colinveaux PA, DeOlivera PE, Moreno JE, Miller MC, Bush MB (1996) A long pollen record from lowland Amazonia: forest cooling in Glacial times. Science 274:85-88

Costa LP (2003) The historical bridge between the Amazon and the Atlantic Forest of Brazil: a study of molecular phylogeography with small mammals. J Biogeogr 30:71-86

Cross S, Baker P, Seltzer G, Fritz S, Dunbar R (2001) Late Quaternary climate and hydrology of tropical South America inferred from an isotopic and chemical model of Lake Titicaca, Bolivia and Peru. Quat Res 56:1-9

Cruz FWJ, Burns SJ, Karmann I, Sharp WD, Vuille M, Cardoso AO, Ferrari JA, Silva Dias PL, Viana OJ (2005) Insolation-driven changes in atmospheric circulation over the past 116,000 years in subtropical Brazil. Nature 434:63-66

Cruz FW, Vuille M, Burns SJ, Wang X, Cheng H, Werner M, Edwards RL, Karmann I, Auler AS, Nguyen H (2009) Orbitally driven east-west anti-phasing of South American precipitation. Nat Geosci 2:210-214

D'Apolito CD, Absy ML, Latrubesse EM (2017) The movement of pre-adapted cool taxa in northcentral Amazonia during the last glacial. Quat Sci Rev 169:1-12 
Dal-Vechio F, Prates I, Grazziotin FG, Zaher H, Rodrigues MT (2018) Phylogeography and historical demography of the arboreal pit viper Bothrops bilineatus (Serpentes, Crotalinae) reveal multiple connections between Amazonian and Atlantic rainforests. J Biogeogr 45:2415-2426

Dansgaard W, Johnsen SJ, Clausen HB, Dahl-Jensen D, Gunderstrup NS, Hammer CU, Hvidberg CS, Steffensen JP, Sveinbjirnsdottir AE, Jouzel J, Bond G (1993) Evidence for general instability of past climate from a 250-year ice core record. Nature 364:218-220

Dexter KG, Lavin M, Torke BM, Twyford AD, Kursar TA, Coley PD, Drake C, Hollands R, Pennington RT (2017) Dispersal assembly of rain forest tree communities across the Amazon basin. Proc Natl Acad Sci U S A 114:2645-2650. https://doi.org/10.1073/pnas.1613655114

Dupont L, Schlutz F, Ewah CT, Jennerjahn TC, Pal A, Behling H (2010) Two-step vegetation response to enhanced precipitation in Northeast Brazil during Heinrich event 1. Glob Chang Biol 16:1647-1660

Erkens RHJ, Chatrou LW, Maas JW (2007) A rapid diversification of rainforest trees (Guatteria; Annonaceae) following dispersal from Central into South America. Mol Phylogenet Evol 44:399-411. https://doi.org/10.1016/j.ympev.2007.02.017

Esquivel-Muelbert A, Baker TR, Dexter KG (2019) Compositional response of Amazon forests to climate change. Glob Chang Biol 25:39-56

Fritz SC, Baker PA, Seltzer GO, Ballantyne A, Tapia P, Cheng H, Edwards L (2007) Quaternary glaciation and hydrologic variation in the South American tropics as reconstructed from the Lake Titicaca drilling project. Quat Res 68:410-420

Fritz SC, Baker PA, Ekdahl E, Seltzer GO, Stevens LR (2010) Millennial-scale climate variability during the Last Glacial period in the tropical Andes. Quat Sci Rev 29:1017-1024

Garzón-Orduña IJ, Benetti Longhini JE, Brower AVZ (2014) Timing the diversification of the Amazonian biota: butterfly divergences are consistent with Pleistocene refugia. J Biogeogr 41:1631-1638

Gentry A (1982) Neotropical floristic diversity: phytogeographical connections between Central and South America. Pleistocene climatic fluctuations or an accident of Andean orogeny? Ann Mo Bot Gard 69:557-593

Haffer J (1969) Speciation in Amazonian forest birds. Science 165:131-137

Hemming SR (2004) Heinrich events: massive late Pleistocene detritus layers of the North Atlantic and their global climate imprint. Rev Geophys 42(1):RG1005

Hermanowski B, Lima da Costa M, Carvalho AT, Behling H (2012) Palaeoenvironmental dynamics and underlying climatic changes in southeast Amazonia (Serra Sul dos Carajas, Brazil) during the late Pleistocene and Holocene. Palaeogeogr Palaeoclimatol Palaeoecol 365-366:227-246

Hoorn C, Wesselingh FP, ter Steege H, Bermudez MA, Mora A, Sevink J, Sanmartin I, SanchezMeseguer A, Anderson CL, Figueiredo JP, Jaramillo C, Riff D, Negri FR, Hooghiemstra H, Lundberg J, Stadler T, Sarkinen T, Antonelli A (2010) Amazonia through time: Andean uplift, climate change, landscape evolution, and biodiversity. Science 330:927-931

Hughes C, Eastwood R (2006) Island radiation on a continental scale: exceptional rates of plant diversification after uplift of the Andes. Proc Natl Acad Sci 103:10334-10339

Jenkins CN, Pimm SL, Joppa LN (2013) Global patterns of terrestrial vertebrate diversity and conservation. Proc Natl Acad Sci 110(28):E2602-E2610

Kanner LC, Burns SJ, Cheng H, Edwards RL (2012) High-latitude forcing of the South American Summer Monsoon during the last Glacial. Science 335:570-573

Kay KM, Reeves PA, Olmstead RG, Schemske DW (2005) Rapid speciation and the evolution of hummingbird pollination in neotropical Costus subgenus Costus (Costaceae): evidence from nrDNA its and ETS sequences. Am J Bot 92:1899-1910. https://doi.org/10.3732/ajb.92.11. 1899

Koenen EJM, Clarkson JJ, Pennington TD, Chatrou LW (2015) Recently evolved diversity and convergent radiations of rainforest mahoganies (Meliaceae) shed new light on the origins of rainforest hyperdiversity. New Phytol 207:327-339. https://doi.org/10.1111/nph.13490 
Lagomarsino LP, Condamine FL, Antonelli A, Mulch A, Davis CC (2016) The abiotic and biotic drivers of rapid diversification in Andean bellflowers (Campanulaceae). New Phytol 210:1430-1442. https://doi.org/10.1111/nph.13920

Lavin M (2006) Floristic and geographical stability of discontinuous seasonally dry tropical forests explains patterns of plant phylogeny and endemism. In: Pennington RT, Lewis GP, Ratter JA (eds) Neotropical savannas and seasonally dry forests: plant diversity, biogeography and conservation. CRC Press, Boca Raton, FL, pp 433-448

Ledru MP, Ceccantini G, Gouveia S, Lopez-Saez JA, Pessenda L, Ribero AS (2006) Millennialscale climatic and vegetation changes in a northern Cerrado (northeast Brazil) since the Last Glacial Maximum. Quat Sci Rev 25:1110-1126

Leite YLR, Costa LP, Loss AC, Rocha RG, Batalha-Filho H, Bastos AC, Quaresma VS, Fagundes V, Paresque R, Passamani M, Pardini R (2016) Neotropical forest expansion during last glacial period challenges refuge hypothesis. Proc Natl Acad Sci U S A 113:1008-1013

Liebsch D, Marques MC, Goldenberg R (2008) How long does the Atlantic Rain Forest take to recover after a disturbance? Changes in species composition and ecological features during secondary succession. Biol Conserv 141:1717-1725

Lisiecki LE, Raymo ME (2005) A Pliocene-Pleistocene stack of 57 globally distributed benthic $\delta 180$ records. Palaeoceanography 20:PA1003

Liu X, Battisti DS (2015) The influence of orbital forcing of tropical insolation on the climate and isotopic composition of precipitation in South America. J Clim 28:4841-4862

Luebert F, Wiegend W (2014) Phylogenetic insights into Andean plant diversification. Front Ecol Evol 2:article 27. https://doi.org/10.3389/fevo.2014.00027

Madriñán S, Cortés AJ, Richardson JE (2013) Páramo is the world's fastest evolving and coolest biodiversity hotspot. Front Genet 4:192

McGee D, Moreno-Chamarro E, Green B, Marshall J, Galbraith E, Bradtmiller L (2018) Hemispherically asymmetric trade wind changes as signatures of past ITCZ shifts. Quat Sci Rev 180:214-228

Moritz C, Patton JL, Schneider CJ, Smith TB (2000) Diversification of rainforest faunas: an integrated molecular approach. Annu Rev Ecol Syst 31:533-563

Mosblech NAS, Bush MB, Gosling WD, Hodell DA, Thomas L, van Calsteren P, Correa-Metrio A, Valencia BG, Curtis J, van Woesik R (2012) North Atlantic forcing of Amazonian precipitation during the last ice age. Nat Geosci 5:817-820

Nace TE, Baker PA, Dwyer GS, Silva CG, Rigsby CA, Burns SJ, Giosan L, Ott-Bliesner B, Liu Z, Zhu J (2014) The role of North Brazil Current transport in the paleoclimate of the Brazilian Nordeste margin and paleoceanography of the western tropical Atlantic during the late Quaternary. Palaeogeogr Palaeoclimatol Palaeoecol 415:3-13

Pedro JB, Jochum M, Buizert C, He F, Barker S, Rasmussen SO (2018) Beyond the bipolar seesaw: toward a process understanding of interhemispheric coupling. Quat Sci Rev 192:27-46

Pennington RT, Prado DE, Pendry CA (2000) Neotropical seasonally dry forests and Quaternary vegetation changes. J Biogeogr 27:261-273

Peterson LC, Haug GH, Hughen KA, Rohl U (2000) Rapid changes in the hydrologic cycle of the tropical Atlantic during the Last Glacial. Science 290:1947-1951

Phillips BL, Brown GP, Greenlees M, Webb JK, Shine R (2007) Rapid expansion of the cane toad (Bufo marinus) invasion front in tropical Australia. Austral Ecol 32:169-176

Pouchon C, Fernández A, Nassar JM, Boyer F, Aubert S, Lavergne S, Mavárez J (2018) Phylogenomic analysis of the explosive adaptive radiation of the Espeletia complex (Asteraceae) in the Tropical Andes. Syst Biol 67:1041-1060

Prado LF, Wainer I, Chiessi CM (2013) Mid-Holocene PMIP3/CMIP5 model results: intercomparison for the South American monsoon system. The Holocene 23:1915-1920

Prates I, Rodrigues MT, Melo-Sampaio PR, Carnaval AC (2015) Phylogenetic relationships of Amazonian anole lizards (Dactyloa): taxonomic implications, new insights about phenotypic evolution and the timing of diversification. Mol Phylogenet Evol 82:258-268 
Prates I, Xue AT, Brown JL, Alvarado-Serrano DF, Rodrigues MT, Hickerson MJ, Carnaval AC (2016a) Inferring responses to climate dynamics from historical demography in neotropical forest lizards. Proc Natl Acad Sci 113:7978-7985

Prates I, Rivera D, Rodrigues MT, Carnaval AC (2016b) A mid-Pleistocene rainforest corridor enabled synchronous invasions of the Atlantic Forest by Amazonian anole lizards. Mol Ecol 25:5174-5186

Prates I, Penna A, Rodrigues MT, Carnaval AC (2018) Local adaptation in mainland anole lizards: integrating population history and genome-environment associations. Ecol Evol 8:11932-11944

Punyasena SW, Mayle FE, McElwain JC (2008) Quantitative estimates of glacial and Holocene temperature and precipitation change in lowland Amazonian Bolivia. Geology 36:667-670

Quijada-Mascareñas A, Ferguson JE, Pook CE, Wuster W (2007) Phylogeographic patterns of Trans-Amazonian vicariants and Amazonian biogeography: the Neotropical rattlesnake (Crotalus durissus complex) as an example. J Biogeogr 34:1296-1312

Rahmstorf S (2002) Ocean circulation and climate during the past 120,000 years. Nature 419:207

Rangel TF, Edwards NR, Holden PB, Diniz-Filho JAF, Gosling WD, Coelho MTP, Cassemiro FAS, Rahbek C, Colwell RK (2018) Modeling the ecology and evolution of biodiversity: biogeographic cradles, museums, and graves. Science 361:244

Reis LS, Guimaraes J, Souza-Filho P, Sahoo PK, Figueiredo M, Giannini T (2017) Environmental and vegetation changes in southeastern Amazonia during the late Pleistocene and Holocene. Quat Int 449:83-105

Richardson JE, Pennington RT, Pennington TD, Hollingsworth PM (2001) Rapid diversification of a species-rich genus of neotropical rain forest trees. Science 293:2242-2245

Rull V, Carnaval AC (2019) Introduction. In: Rull V, Carnaval A (eds) Neotropical diversification. Springer, Heidelberg

Santos JC, Coloma LA, Summers K, Caldwell JP, Ree R, Cannatella DC (2009) Amazonian amphibian diversity is primarily derived from late Miocene Andean lineages. PLoS Biol 7(3): e1000056

Schrag DP, Adkins JF, McIntyre K, Alexander JL, Hodell DA, Charles CD, McManus JF (2002) The oxygen isotopic composition of seawater during the Last Glacial Maximum. Quat Sci Rev 21:331-342

Steig E, Alley R (2002) Phase relationships between Antarctic and Greenland climate records. Ann Glaciol 35:451-456

Stodart E, Parer I (1988) Colonisation of Australia by the rabbit Oryctolagus cuniculus (L.). CSIRO, Canberra

Stute M, Forster M, Frischkorn H, Serejo CP, Broecker WS (1995) Cooling of tropical Brazil during the last glacial maximum. Science 269:379-383

Sylvestre F, Servant M, Servant-Vildary S, Causse C, Fournier M, Ybert JP (1999) Lake-level chronology on the southern Bolivian Altiplano $\left(18-23^{\circ} S\right)$ during late-Glacial time and the early Holocene. Quat Res 51:54-66

van der Hammen T, Cleef AM (1986) Development of the high Andean páramo flora and vegetation. In: Vuilleumier F, Monasterio M (eds) High altitude tropical biogeography. Oxford University Press, New York, pp 153-201

Vanzolini P, Williams E (1970) South American anoles: the geographic differentiation and evolution of the anolis Chrysolepis species group (Sauria, Iguanidae). Arquivos de Zoologia 19:125-298

Vargas OM, Dick CW (2019) Diversification history of Neotropical Lecythidaceae, an ecologically dominant tree family of Amazon rain forest. In: Rull V, Carnaval A (eds) Neotropical diversification. Springer, Heidelberg

Vargas OM, Simpson BB (2019) Allopatric speciation versus parapatric ecological divergence in high Andean plants (Asteraceae: Piofontia). bioRxiv:868216. https://doi.org/10.1101/868216

Vellinga M, Wood RA (2002) Global climatic impacts of a collapse of the Atlantic thermohaline circulation. Clim Chang 54:251-267 
Voelker AH (2002) Global distribution of centennial-scale records for Marine Isotope Stage (MIS) 3: a database. Quat Sci Rev 21:1185-1212

Wang X, Edwards RL, Auler AS, Cheng H, Kong X, Wang Y, Cruz FW, Dorale JA, Chiang H-W (2017) Hydroclimate changes across the Amazon lowlands over the past 45,000 years. Nature 541:204-207

Wehtje W (2003) The range expansion of the great-tailed grackle (Quiscalus mexicanus Gmelin) in North America since 1880. J Biogeogr 30:1593-1607

Wheatley A et al (2019) Modeling the origins of biodiversity in the tropical Andes (manuscript in preparation)

Wiens JJ (2004) Speciation and ecology revisited: phylogenetic niche conservatism and the origin of species. Evolution 58:193-197

Zhang Y, Chiessi CM, Mulitza S, Sawakuchi AO, Haggi C, Zabel M, Portioho-Ramos C, Schefuß E, Crivellari S, Wefer G (2017) Different precipitation patterns across tropical South America during Heinrich and Dansgaard-Oeschger stadials. Quat Sci Rev 177:1-9 